\title{
Reviewing the Maintenance of Acehnese Language from the Language Policy and Planning Perspectives
}

\author{
${ }^{* 1}$ Refanja Rahmatillah, ${ }^{2}$ Veni Nella Syahputri, ${ }^{3}$ Endah Anisa Rahma, ${ }^{4}$ Rizki Fajrita \\ *1Universitas Teuku Umar, Indonesia, refanjarahmatillah@utu.ac.id \\ ${ }^{2}$ Universitas Teuku Umar, Indonesia, veninellasyahputri@utu.ac.id \\ ${ }^{3}$ Universitas Teuku Umar, Indonesia, endahanisarahma@utu.ac.id \\ ${ }^{4}$ Universitas Syiah Kuala, Indonesia, rizki.hasballah@gmail.com
}

\section{Submitted: DD/MM/YYYY Revised: DD/MM/YYYY Accepted: DD/MM/YYYY}

How to cite this article: Rahmatillah, R., Syahputri, V. N., Rahma, E. N., \& Fajrita, R. (2021). Reviewing the maintenance of Acehnese language from the language policy and planning perspectives. International Journal of Education, Language, and Religion, 3(2), 82-88. doi: 10.35308/ijelr.v3i2.4529

\begin{abstract}
For over the last decade, the number of Acehnese speakers has continuously declined. The obstruction of Acehnese transfer from one generation to the next generation is believed to contribute to this condition. This paper addresses the role of language policy and planning to overcome the mentioned problem. The situation of Acehnese use and the studies related to this topic are reviewed to conclude the suggestions for the improvement of Acehnese language policy and planning. The results of the review indicate that the Acehnese language policy and planning is not well prepared, specifically related to corpus planning which affects Acehnese teaching in school. In addition, the local government does not optimally support the efforts of using Acehnese in public.
\end{abstract}

\section{Keywords}

Acehnese; language maintenance; language policy; language planning; government

\section{Introduction}

Acehnese is one of ethnic language spoken in the province of Aceh, the north-western tip province of Sumatera Island, Indonesia. The Statistics Center Agency (BPS) reveals that over the year 2000 to 2010, the number of Acehnese speakers is continuously decreasing from around 3,5 million speakers (Simons \& Charles, 2018) to 2,5 million (Badan Pusat Statistik, 2012). The existence of Indonesian language, which has a higher status compared to Acehnese, is believed to be one of contributing factors for this situation. The use of Indonesian as the official language in Indonesia and the medium of instruction language in schools is considered more favorable, specifically by Acehnese parents for the success of their children. This favor of the language has directed some parents to interact with their children in Indonesian as their first language (Alamsyah, Taib, Azwardi, \& Idham, 2011). This decision may result in the obstruction of the intergeneration Acehnese language transfer. 
The efforts of Acehnese, as well as Indonesian government, to maintain the ethnic language seem to have unsatisfactory results. The teaching of Acehnese in schools which has began since 1970s does not result in more competent of Acehnese users (Yusuf et al., 1986), especially for writing skills. Here indicates that there is a problem with the Acehnese language policy and planning carried out by the government. The language policy and planning thus need to be improved for it can influence the language policy taken at family level to be more positive towards Acehnese language.

\section{The Role of Language Policy and Planning in Language Maintenance}

Language policy and planning cannot be separated from one to other. Language policy acts as the first step of government in creating regulations related to language problems, while language planning is the follow-up actions towards the regulations. According to Schiffman (cited in Johnson 2013), the scope of language policy and planning does not longer apply only to government, as the initiator and actor, but also to all levels of stakeholders, including families, as the lowest, yet the most crucial actor. In addition, language policies cannot be separated and, in fact, interconnected to language ideologies (Johnson, 2013). Language policies can be either a result from existing language ideologies or a cause for language ideologies to exist. Language policies may also be comprehended differently by different individuals or groups according to the language ideology that they hold. This connection between language policies and language ideologies, furthermore, may even influence the pattern of language practices. This effect is commonly comprehended as the result of the power of language policies.

The power of language policies on language practices commonly becomes a problem when it is imposed on minority languages. As explained by Johnson (2013), language policies, which mostly deal for majority languages interests, historically provide threats to minority languages, for example by limiting the uses of the language. Nevertheless, language policies can be also utilized, by designing and revising the policies, to support the maintenance of minority languages. Therefore, concepts of language policy and planning need to be studied in order to accommodate the advantages for minority language preservation.

Lo Bianco (2010) categorizes five types of language planning in language policy and planning concept.

1. Status Planning. Status planning is the planning to appoint a status of a language which is usually executed by authorized government or people. This process is vital since it will shape the perception and anticipation of society towards the language.

2. Corpus Planning. Corpus planning is the planning to standardize the form of a language. This process needs to be carefully carried out and, thus, mostly executed by linguists for the purpose of effective representation of the language and acceptance of society.

3. Acquisition Planning. Acquisition planning is the planning to make the language is acquired by the younger generation, which is mostly done by the process of teaching the language. This process is needed to reinforce the existence of the language once the corpus planning is completed.

4. Usage Planning. Usage planning is the planning to promote the use of the language. This process can be done providing more domains for the language to be used.

5. Prestige Planning. Prestige planning is the planning to attach a prestigious status to the language. Prestige planning as well as the usage planning aims to improve the acceptance of the society towards the language.

These five types of planning, according to Lo Bianco (2010), are interdependent and, thus, each process can be carried out in any order. For the purpose of language maintenance, all these processes must be carefully monitored and optimally utilized.

The processes of language planning themselves seem to be motivated by the orientations of language views. There are three orientations of language views introduced by Ruiz (in Hult \& Hornberger, 2016) which are commonly used by scholars in analyzing language policy and planning. The views of language 
are language as problem, language as right, and language as resource. In relation to language maintenance, the optimalization of language as resource view is crucial. This is because in this view, linguistic diversity is encouraged and appreciated as part of national unity. As a result, bi/multilingualism is supported to exist in school and linguistic minorities are perceived as a valuable content for the multilingual development. In addition to language as resource view, there is also promotion-oriented policy proposed by Kloss and Wiley (cited in Johnson, 2013). This orientation offers benefits for minority languages since the government will act to provide supports to promote the use of the language. Therefore, by applying these orientations in the language policies and planning, the minority language maintenance can be optimally achieved.

In addition, the process of language maintenance should also consider the actors who are involved in the process. While the traditional theories of language policy and planning refer solely authorities or government as the actors, since they have wider and stronger (macro-level) effect from the policies that they issue (Zhao, 2011), the current discussion focus on the role of micro-level actors. The micro-level actors include individuals, families, and other small organizations. Specifically for individuals, Petrovic and Kunts (2013) state that the existence of individuals' agency in implementing the language policies is needed to be paid attention to assure that they will not question, reinterpret or counter the policies. Meanwhile, for families, Tollefson (2006) argues that the role of parents in using their family-level power is crucial for language maintenance process since their actions are mostly influenced by their ideology towards the language. As mentioned earlier, parents' language ideology which is shaped by the macro-policies applied, determine their positivity towards the language.

After understanding how the concept of language policy and planning relates to the language maintenance process, an exploration on how the language policy and planning in maintaining Acehnese language needs to carried out. Previous research on Acehnese language use does not comprehensively link the role of language policy and planning in the current Acehnese language condition. Thus, this paper will review the position of language policy and planning in the process of maintaining Acehnese language.

The objective will be addressed by firstly reviewing the history of the status of Acehnese after joining the Republic of Indonesia. After that, all efforts that have been carried out to maintain Acehnese language will be analyzed to seek for aspects that can be improved. Finally, it will point out the role of government and parents in preserving the language.

\section{Method}

This paper is a position paper that establishes an argument towards an issue by studying the available literature related to the issue. There are 20 studies exploring Acehnese language and status that are reviewed in this paper. The studies were mostly retrieved from online storage and they were dated from 1980 s to 2010s. The studies were then analyzed to look at the category of discussion relating to the issue and then were mentioned in the appropriate places.

\section{Results and Discussion}

\section{The Usage and Situation of Acehnese Language Use}

The usage of Acehnese language is typically at circle of relatives, village, or casual contexts. meanwhile for formal contexts, including colleges and places of work, Indonesian is desired. A study conducted by Al-Auwal (2017) shows that the university students living in Banda Aceh (the capital city of Aceh) preferred to use Indonesian for their daily life communication. This choice is argued due to the senses of Indonesian is more modern while Acehnese is considered harsh; Indonesian is more convenient to speak than Acehnese; and Acehnese is used more for making jokes. The choice of using Indonesian in 
everyday communication is also found in Fakhrurrazi (2016) where the native Acehnese speakers in Langsa (a city in East Aceh) use Indonesian for school, religion, and community context.

The current choice of preferring Indonesian rather than Acehnese can actually be traced from the history perspective. It emerges within the past (before and in the early of Aceh becoming a member of the Republic of Indonesia) that the language used in the royal courtroom and for external relations was Malay or Indonesian (Durie, 1996). However, during this period, as shown by way of Durie (1996), there have been some publications produced by way of using Acehnese language, which includes history and collection of poets. At some stage in the early independence of Indonesia, particularly, those publications are consistent with the orientation of language as useful resource determined by the government in 1945 Constitution, which valued and supported the use of local languages as a part of the subculture of Indonesia and the enrichment of Indonesian lexicon (Yusuf, Faridan, Ajies, and Wahab, 1986). As a result, it can be concluded that the popularity of ethnic languages, including Acehnese, is considered positive and crucial, even though Indonesian is selected for the formal contexts.

The distinctive orientation of language is implemented throughout the regime of Soeharto, the second president of Indonesia, in which the point of interest is to unite the nation and the local languages is seen as a problem. This orientation regarded linguistic diversity as an obstacle to the country harmony and hence the use of Indonesian is compelled (Kirkpatrick, 2010). The promoting of Indonesian began with the status of Indonesian as a compulsory subject and the medium of instruction in schools. The status of ethnic languages that was promoted in the preceding regime is not maintained. As the outcome of this policy, the quantity of speakers of ethnic languages is constantly lowering in the course of the length of Soeharto's authorities, meanwhile the users of Indonesian in each day life are dramatically growing (see table below). Acehnese itself, that is covered in 'others' category, is likewise assumed to revel in the decrease of quantity of speakers throughout the enforcement of Indonesian use.

Table 1. Language users in Indonesia throughout three decades

\begin{tabular}{lllll}
\hline No. & Language & 1980 & 1990 & 2000 \\
\hline 1. & Javanese & $40.44 \%$ & $38.08 \%$ & $34.70 \%$ \\
\hline 2. & Sundanese & $15.06 \%$ & $15.26 \%$ & $13.86 \%$ \\
\hline 3. & Madurese & $4.71 \%$ & $4.29 \%$ & $3.78 \%$ \\
\hline 4. & Batak & $2.12 \%$ & $1.97 \%$ & $1.91 \%$ \\
\hline 5. & Minangkabau & $2.42 \%$ & $2.23 \%$ & $2.06 \%$ \\
\hline 6. & Balinese & $1.69 \%$ & $1.64 \%$ & $1.42 \%$ \\
\hline 7. & Buginese & $2.26 \%$ & $2.04 \%$ & $1.91 \%$ \\
\hline 8. & Indonesian & $11.93 \%$ & $15.19 \%$ & $34.00 \%$ \\
\hline 9 & Others & $17.48 \%$ & $17.11 \%$ & $4.57 \%$ \\
\hline 10. & No answer & $0.76 \%$ & $0.45 \%$ & $0.31 \%$ \\
\hline
\end{tabular}

Source: Montolalu \& Suryadinata (2007)

The apprehension of ethnic languages preservation really has been aroused in 1975, with the establishment of Badan Bahasa or Balai Bahasa (Language offices), that is unfold throughout the provinces in Indonesia (Arka, 2013). Despite its essential challenge that is to address the is sues of neighborhood languages in Indonesia, this frame mostly produce works inside the studies and development of Indonesian language. Therefore, it can be considered that this agency fails to perform its function and this impacts at the disruption of ethnic languages improvement. This example may be also assumed to occur due to the language policy implemented on this time that is to prioritize the use of Indonesian.

Any other effort has also been made in 1975 by means of imposing the teaching of local languages in elementary and junior high schools (Yusuf et al., 1986). This is included as a mandatory local content subject that is taught for 2 hours per week. Moreover, some ethnic languages are allowed to be the 
medium of training for the first three years of elementary school (Bernard, cited in Kirkpatrick 2010). However, the implementation of each the teaching and the use of ethnic languages as the medium of instruction are far from the expectancy. The minimum assist from authorities, mainly from Balai Bahasa in improving the teaching of ethnic languages, is taken into consideration to be the inhibited factor for the realization of this language policy and planning.

Inside the context of Acehnese language, the teaching has been started from 1976 with the decree of the Department of Education and Culture of Aceh Province (Yusuf et al., 1986). Primarily based on the findings of Yusuf et al. (1986), despite the ten-year introduction, this teaching has now not been completely carried out in all schools in Aceh, neither for the use of Acehnese as the medium of instruction. Even for schools that did practice this teaching, its execution became now not powerful. Several factors contributing to this case stated by the researchers had been the absence of the emphasis of the significance of Acehnese language, the incompetent teachers, and the variance of Acehnese language used in the textbook. Referring to the last factor, it appears obvious that the corpus planning for this language was not properly implemented which interrupts the application of acquisition planning.

The study of standardizing language has taken account for many language experts, which also applies for the case of standardizing Acehnese language. Asyik (1987), for example, focused his study about grammar of Acehnese sentence to contribute to the standardized Acehnese syntax. In addition, he stated that the efforts of Acehnese language standardization have been mostly conducted by Syiah Kuala University researchers. The researchers emphasized the difference of the standard writing system between Acehnese and Indonesian. However, the emphasis is not effective to persuade the Acehnese people to follow their writing system style. It is as argued by Durie (1996) who states that many writers do not come along with the Syiah Kuala University standard writing form. Instead, they use their Indonesian literacy to represents Acehnese words. This argument is confirmed in the more recent study (Yulia, 2009). She finds out that most students in her study transfer their Indonesian literacy knowledge to write Acehnese words. This might be caused by the low status of Acehnese language subject in schools and the absence of Acehnese spelling introduction in early classes. From these findings, it can be implied that the corpus planning of Acehnese is not well-executed, especially in education area, and the Indonesian literacy heavily impacts Acehnese people to write their own language. Based on the issue, it is very crucial to firstly establish the corpus planning of Acehnese before it can improve to the prestige planning of Acehnese, which aims for the Acehnese people not feeling inferior when using Acehnese in academic context.

The status of Indonesian as the medium of instruction in educational setting in Indonesia also influence the language choice of parents in Aceh. Students who do not master Indonesian will fail to achieve the academic life and, thus, making the parents to teach Indonesian as their children's first language. The study from Alamsyah et al. (2011) reveal one of the reasons of the Acehnese family language policy is because the parents have unpleasant experience of being not able to speak Indonesian well in school. They were humiliated by their friends and they could not show their potential in answering teachers' questions despite they know the answers. This negative perception of parents as a crucial agent in language maintenance (Canagarajah, 2008; Fishman, 1990; Tollefson, 2006), slowly become a threat toward Acehnese language maintenance. The effect of language policies in schools significantly form the language ideology of parents Spolsky (2012), including the Acehnese parents' language ideology. Therefore, it can be concluded that the implementation of Indonesian in instructional setting form the Acehnese people's perception that Indonesian is a privilege language.

According to Spolsky (cited in Pillai, Soh, \& Kajita, 2014), language ideology can be analyzed in family language policy, in addition to the analysis of language practices and language management of the family. All these variables can be analyzed in relation to language maintenance. Ulfa (2017), for example, shows that the tradition to embrace Acehnese language, even in intermarriage family, contribute positively to the language maintenance. Pillai et al. (2015), in addition, describe how 
Acehnese community in Kedah, Malaysia tries to keep Acehnese language alive by providing opportunities to use Acehnese in public. Regarding the case of Acehnese parents' language ideology which is shaped by the privilege use of Indonesian language, it is assumed that Indonesian language will be mostly spoken because of language practice and language management policies. It is supported by the statement from Alamsyah et al. (2011) that the Acehnese parents in their study apply language practices of using Indonesian to their children. Badan Pusat Statistik (2012) and Simon and Charles (2018) also mention that Acehnese users use this language as the vernacular language around 2,5 million, decreasing 1 million of users in 2000 census. From the data, it can be inferred that the change of language policy of the family context, which also be influenced by the movement of government, is very crucial to be raised up in order to maintain Acehnese users.

\section{Conclusion}

Language policy and planning is very important in the process of language maintenance. From the issue of decreasing number of Acehnese speakers, it is clear that the case of Acehnese language maintenance is still not well-prepared, especially in the process of corpus planning, since it can be one of the obstacles of Acehnese language teaching at schools. In addition, the lack of government's actions to emphasize the importance of Acehnese language in educational setting influence the language policy of Acehnese families' context which led parents to teach Indonesian as their children's mother tongue. The government needs to pay more attention on the inclusion of Acehnese language in education settings in order to shape the better perception of Acehnese parents towards Acehnese language. Referring to 2009 regulations no. 24, the current responsibilities about maintaining local languages is mainly under local governments (Arka, 2013). Therefore, the government can start by improving the corpus planning of Acehnese language and then introduce it to public, which may affect the Acehnese teaching in school to be more effective.

\section{References}

Alamsyah, T., Taib, R., Azwardi, \& Idham, M. (2011). Pemilihan bahasa Indonesia sebagai bahasa pertama anak dalam keluarga masyarakat Aceh penutur Bahasa Aceh di Nanggroe Aceh Darussalam [The selection of Bahasa Indonesia as the children's first language in families from the Acehnese speaking community who are in Nanggroe Aceh Darussalam]. Jurnal Pendidikan Bahasa Melayu, 1(2): 31-34. Retrieved from http://journalarticle.ukm.my/3181/

Al-Auwal, T. M. R. (2017). Reluctance of Acehnese youth to use Acehnese. Studies in English Language and Education, 4(1), 1-14.

Arka, I. W. (2013). Language management and minority language maintenance in (Eastern) Indonesia: Strategic issues. Language Documentation \& Conservation, 7, 74-105.

Asyik, A. G. (1987). A contextual grammar of Acehnese sentences. (Doctoral dissertation, University of Michigan, Ann Arbor, United States of America). Retrieved from http://acehbooks.org/search/detail/3945?language=en

Badan Pusat Statistik. (2012). Kewarganegaraan, suku bangsa, agama, dan bahasa sehari-hari penduduk Indonesia [Nationality, ethnics, religions, and daily languages of Indonesians]. Jakarta: Badan Pusat Statistik.

Canagarajah, A. S. (2008). Language shift and the family: Questions from the Sri Lankan Tamil diaspora. Journal of Sociolinguistics, 12(2), 143-176.

Durie, M. (1996). Framing the Acehnese text: language choice and discourse structures in Aceh. Oceanic Linguistics, 35(1), 113-137. doi: 10.2307/3623033

Fakhrurrazi, F. (2016). Attitudes of indigenous Acehnese people towards their vernacular maintenance in Langsa. JL3T (Journal of Linguistics Literature and Language Teaching), 2(2), 124-146.

Fishman, J. A. 1990. What is reversing the language shift (RLS) and how can it succeed? Journal of Multilingual and Multicultural Development, 11. 5-36. 
Hult, F. \& Hornberger, N. H. (2016). Revisiting orientations in language planning: Problem, right, and resource as an analytical heuristic. Bilingual Review, 33(3), 30-49.

Johnson, D. C. (2013). Language policy. London: Palgrave Macmillan.

Kirkpatrick, A. (2010). English as a lingua franca in ASEAN. Hongkong: Hongkong University Press.

Lo Bianco, J. (2010). Language policy and planning. In N. H. Hornberger \& S. L. McKay (Eds.), Sociolinguistics and language education (pp. 143-174). Bristol: Multilingual Matters.

Montolalu, L. R., \& Suryadinata, L. (2007). National language and nation-building: the case of Bahasa Indonesia. In L. H. Guan \& L. Suryadinata (Eds.), Language nation and development in Southeast Asia. Singapore: Institute of Southeast Asian Studies.

Petrovic, J. E. \& Kuntz, A. M. (2013). Strategies of reframing language policy in the liberal state: A recursive model. Journal of Language and Politics, 12(1), 126-146.

Pillai, S., Soh, W. Y, \& Kajita, A. (2014). Family language policy and heritage language maintenance of Malacca Portuguese Creole. Language \& Communication, 37, 75-85.

Pillai, S., Soh, W. Y., \& Yusuf, Y. Q. (2015). Perceptions about One's Heritage Language: The Case of the Acehnese in Kampung Aceh and Malacca Portuguese-Eurasians in the Portuguese Settlement in Malaysia. Kemanusiaan: The Asian Journal of Humanities, 22(2), 67-92.

Simons, G. F. \& Charles, D. F. (2018). Ethnologue: Languages of the World (21th ed.). Dallas, Texas: SIL International. Retrieved April 7, 2018 from https://www.ethnologue.com/language/ace

Spolsky, B. (2012). Family language policy - The critical domain. Journal of Multilingual and Multicultural Development, 33(1), 3-11.

Tollefson, J. W. (2006). Critical theory in language policy. In T. Ricento (Ed.), An introduction to language policy (pp. 42-59). Malden, MA: Blackwell Malden, MA: Blackwell.

Ulfa, M. (2017). Maintenance of Acehnese terms of address in an intermarriage family. Studies in English Language and Education, 4(1), 76-91.

Yulia, A. (2009). Does the spoken language help or hinder the spelling in the second language? A case of Indonesian and Acehnese language. (Master's thesis, Texas A\&M University, Texas, United States of America). Retrieved from https://oaktrust.library.tamu.edu/bitstream/handle/1969.1/ETD-TAMU-2009-05-530/YULIATHESIS.pdf?sequence $=2 \&$ isAllowed $=y$

Yusuf, S., Faridan, A., Ajies, A.M.E., \& Wahab, S. M. (1986). Pengajaran bahasa Aceh di SMTP propinsi Daerah Istimewa Aceh [The Acehnese language teaching in junior high schools of Aceh province]. Jakarta: Pusat Pembinaan dan Pengembangan Bahasa Departemen Pendidikan dan Kebudayaan.

Zhao, S. (2011). Actors in language planning. In E. Hinkel (Ed.), Handbook of research in second language teaching and learning (pp. 905-923). New York; London: Routledge. 